\title{
The Implications Of Granting Backdated Options
}

\author{
James E. Owers, Georgia State University and Harvard University
}

\begin{abstract}
Option backdating has recently been receiving extensive attention. The remarkable pattern of stock prices systematically declining before and increasing after the granting of options has been documented in research papers for approximately a decade but only recently have firms been facing charges of improper procedures associated with this pattern. One associated issue remaining to be investigated is what the implications are for shareholders of affected firms. This paper addresses that issue. It finds that there are marked negative implications for stockholders. On average, when investigations into backdating are announced firms lose approximately $11 \%$ of their market value. This translates into an average decline of more than half a billion dollars in market capitalization in the month leading up to the formal announcement of an investigation.
\end{abstract}

\section{INTRODUCTION}

$\mathrm{n}$ this paper, the key focus is the stock value implications of announcements that firms are being investigated for issuing backdated options. As background, the circumstances of options backdating are outlined from accounting and legal perspectives. This issue is of paramount importance for several

\section{e} reasons. The practice is generally considered to be unethical even if not always illegal. As the New York Society of CPAs note, "Stock options backdating does not inherently violate any federal mandates. But for companies that lack visibility into the options issuance processes, options backdating can create real business risks because of SEC

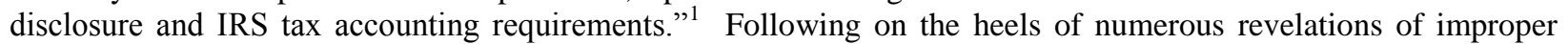
practices in the 1990s, the finding that corporate mischief continued on such a substantial scale into the new millennium is widely considered to be a concern. It is yet another factor for investors who are seemingly increasingly concerned about whether the stock market is a "level playing field" for making risk/return tradeoffs relating to investment decisions.

Backdating has generated some spectacular press reports. One of the more notable is that relating to Comverse Technology Inc., the circumstances of which are summarized later in the paper. The granting of backdated options includes both direct costs (the understated compensation) but also seemingly much larger indirect costs associated with the associated reputational risk.

Because backdating generally results in firms underreporting executive compensation, it requires the restatement of accounting data (including possibly a one-time write-off) for the period of backdating. ${ }^{2}$ Accounting restatements have been increasingly rapidly in recent times and the number of restatements reached new notable levels. For public companies traded in the United States, the increase has been from 59 restatements in 1997 to 1420 in 2006. In addition, the dollar magnitude of restated amounts has increased more than proportionately. The relatively recent definitive conclusion that the remarkable pattern of stock price changes around the issue of many executive options backdating is generally the result of "mischief" rather than the "good predictor" capabilities of Board members and top managers is prompting another round of restatements.

\footnotetext{
${ }^{1}$ The CPA Journal Online, New York Society of CPAs, April 2007.

${ }^{2}$ In some case the interval can be very lengthy. Home Depot reportedly had backdating that took place over an interval from approximately 1979 until 2000.
} 
In this paper we examine the stock value implications of upcoming accounting restatements associated with options backdating and the implied governance deficiencies as major contributors to the widely discussed increase in investor skepticism and decline in confidence regarding equity investments. In the early years of the new millennium, there was a long period wherein equity instruments overall did not provide the customary rates of return. This global decline of security values followed a period of both "irrational exuberance" and the (subsequent) revelation of quite widespread accounting problems. There were several causes of this decline in confidence, of which accelerated accounting restatements and revealed governance deficiencies are prominent.

In response to this situation, substantive initiatives such as Sarbanes-Oxley were taken to address the problems. One of the reporting requirements contained in Sarbanes-Oxley was that options grants be reported within two business days. This led to the opportunity to definitively test whether the pattern of stock price declines before options grants and increases after that have been documented in research were the results of managers' "good predictor" insights or backdating practices.

If backdating is found to have taken place, this will require accounting restatements to reflect the impact. ${ }^{3}$ The heightened overall restatement activity has received increasing attention both as to its causes and consequences. The purpose of this paper is to systematically examine the dimension of upcoming accounting restatements resulting from the issue of backdated, in-the-money options. It transpires that there are several reasons for accounting restatements, and the informational content (and associated revaluations) varies notably across categories. Previous studies have identified nine categories of restatements according to the reason provided for their necessity. The high frequency of restatements has led to heightened concern by the SEC and investors. Turner and Weirich (2007) provide an interesting analysis regarding the level and mechanics of restatements. They undertake a detailed analysis of restatements and raise the issue of stealth restatements that do not meet regulatory requirements. Their analysis leads to the conclusion that $14 \%$ of restatements are such stealth restatements.

However, there is some emerging evidence that Section 404 of Sarbanes-Oxley is having the desired impact in terms of reducing restatements. While restatements continue to increase overall, accelerated filers already complying with Section 404 experienced a reduction in restatements in 2006.

The SEC has recently recognized the extent of upcoming restatements associated with options backdating. On January 16, 2007, the Chief accountant of the SEC's Division of Corporate Finance posted a "Sample Letter Sent in Response to inquiries Related to Filing Restated Financial Statements for Errors in Accounting for Stock Option Grants." This reflected the reality that several years could be involved and that in order to reduce the burden on restating companies and confusion for their stockholders, the total effect of the restatement can be made in an amendment to the most recent $10-\mathrm{K}$ filing.

In this study we focus the empirical analysis on the impact of options backdating problems on a firm's stock price and aggregate market capitalization. Having identified some of the major background factors above, the remainder of the paper is organized in the following manner. The next section provides some insights of this activity by way of anecdotes from firms that have issued backdated options. Section 3 considers the regulatory context and related literature. The sample selection procedures and resulting empirical sample are described in section 4 . Section 5 details the event study methodology and Section 6 presents the findings. The paper ends with a summary and indication of subsequent research topics.

\section{THE BACKDATING OF STOCK OPTIONS GRANTS: AN OUTLINE OF SELECTED SCENARIOS}

A significant number of companies are being probed for irregularities related to the issuance of backdated, in-the-money options. Companies formally facing investigations into such practices number around 160 as of August 2007 but this revelation process is seemingly in its early stages and estimates up to $20 \%$ of public companies having potential exposure have been raised.

\footnotetext{
${ }^{3}$ The announcements examined in this paper are not the actual restatements themselves but rather the existence of a formal investigation that might lead to eventual restatements.
} 
Apart from the federal investigations, numerous companies have voluntarily launched their own internal investigations to look into the irregularities related to backdating of options. Several instances where the options were backdated were found. Some executives in these companies are facing civil and criminal charges. Also several companies have restated several years of earnings as they found instances of backdating of options. The cases of Comverse and UnitedHealth provide profiles of the activity.

\section{Comverse Technology Inc}

One of the most prominent companies involved in the options scandal is Comverse. It initially received an inquiry from the SEC following which it has launched its internal investigation. Later the SEC started a criminal investigation on three of its executives, following which all three of them have resigned. After being criminally charged Chief Executive Kobi Alexander (who holds a dual citizenship of Israel and United States) fled from United States. He was later arrested in Namibia and released on bail. Additional details of this interesting anecdote have been widely reported in the press, both financial and general.

After a preliminary review of its stock-option practices, Comverse expected to restate more than five years of financial results because it found that the grant dates used in its accounting differed from the actual grant date. Also it was found that Chief Executive Kobi Alexander frequently received option grants dated just before a sharp rise in the company's share price, sometimes after a steep fall. Seven grants to Mr. Alexander between 1994 and 2001 preceded double-digit run-ups in the share price over the next 20 trading days. Between 1995 and Jan 31, 2005 Kobi Alexander realized $\$ 135$ million in gains from exercising options; he had \$50 million in unrealized gains remaining at the end of that period.

Mr. Alexander, former finance chief David Kreinberg, and former senior general counsel William Sorin resigned from their posts after the federal prosecutors began a criminal investigation. They have admitted having backdated options. Their actions included misleading auditors and attempting to alter computer records to hide a secret options-related "slush" fund, originally nicknamed "I.M. Fanton". Comverse shares lost approximately 17\% of their value in three days around the announcement of the investigation. Overall, the value of the firm's shares declined in this short interval by approximately $\$ 800$ million.

\section{UnitedHealth Group Inc}

UnitedHealth is another of the prominent firms to be involved in the options scandal. It has received inquiries from SEC following which it has launched its own internal probe. Based on the recommendations from this internal probe it has revamped its corporate governance policy. It also faced pressure from shareholder groups like Calpers which have withheld their votes in electing the new directors.

During its internal investigation it was found that several of its top executives have regularly received option grants just prior to substantial run-ups in share price, often after steep declines. Chief Executive William McGuire received 12 grants between 1994 and 2002, each time just before a rise in the company's share price. Grants in 1997, 1999 and 2000 all were dated on the stock's lowest closing price of the year. Chief Operating Officer Stephen J. Hemsley received some option grants on the same grant dates as William McGuire. At the end of 2005 William McGuire held exercisable options that the company valued at $\$ 1.6$ billion. His options not yet exercisable were valued at $\$ 175$ million. Stephen Hemsley's exercisable options were valued at $\$ 663$ million and unexercisable options at $\$ 82$ million at the end of 2005. But following its internal investigation it suggested that its restatement could total $\$ 286$ million. After the initial inquiry the SEC has also started a criminal probe against United Health.

United Healthcare's stock lost more than 5\% of its value in the month up to the formal announcement of the investigation. This represented an aggregate decline in shareholder wealth (i.e. the firm's "Market Capitalization") of over $\$ 4$ billion. The shares lost another $5 \%$ in the two weeks following the formal announcement of the investigation. 
With approximately 160 companies currently under investigation and some studies estimating that up to $20 \%$ of all public companies may have a backdating exposure, there are of course many interesting anecdotes. Other companies that provide notable anecdotes include Monster Worldwide, Mercury Interactive Technologies, and Vittesse. Some of these cases include circumstances that would be seemingly apocryphal but are nevertheless factual.

\section{THE REGULATORY CONTEXT AND LITERATURE REVIEW}

\section{Regulatory Guidelines}

Guidelines for addressing circumstances requiring accounting restatements come from both the SEC and the Accounting Professional guidelines.

The SEC requires managers to make prompt disclosure of material facts when the earlier statements no longer have a reasonable basis. Specifically, the SEC states that "there is a duty to correct statements made in any filing, whether or not the filing is related to a specified transaction or event, if the statements either have become inaccurate by virtue of subsequent events, or are later discovered to have been false and misleading from the outset, and the issuer knows or should know that persons are continuing to rely on all or any material portion of the statements." (SEC Accounting Rule No. 6084, SEC Docket 1048, 1979).

The criteria for restatement of prior period's interim financial statements are set forth in Statement of Financial Accounting Standards No. 16. It indicates that "Interim prior period restatement is restricted to material nonrecurring adjustments or settlements of litigation or similar claims, income taxes, re-negotiation proceedings, or utility revenue under the rate-making process." Accounting series Release No. 177 also requires that "the registrant shall provide a narrative analysis of the results of operations explaining the reasons for material changes in the amount of revenue and expense items...."

Additional requirements have been introduced under the provisions of Sarbanes-Oxley introduced above. The extent of restatements associated with options backdating is reflected in the previously referenced SEC letter dated January 16, 2007.

\section{Literature}

\section{Research On Timing Of Granting Options}

Over the past decade, there has developed a growing body of literature relating to the timing of the award of stock options to executives (and in some cases to board members themselves). It is well established that firms' stock prices overall are notably positive after executive stock grants. Yermack (1977) and Aboody and Kasznik (2000) are widely cited as having documented the notable post-grant performance of granting firms' stock prices. These studies have documented an abnormal return in the 50 trading days after grants in the order of $2 \%$ and raised the issue of "spring-loading" whereby option grants are issued prior to the release of positive information.

Subsequent studies have documented the additional overall pattern of stock price performance to be abnormally poor before the granting of executive options. These studies include Chavin and Shenoy (2001) and Lie (2005). These studies have received considerable attention and there has been commentary on these patterns in the financial press (MacDonald and Brown [2005]). Reviewing these finding led Lie (2005) to observe that "unless executives have an informational advantages that allows them to develop superior forecasts regarding the future market movement that drive these predicted returns, the results suggest that the official grant date must have been set retroactively." Taking specific cases, there have been press reports of analyses concluding that there is a one-inmillions chance of the opportunistic granting dates having been fortuitous.

Lie (2007) took advantage of the changes in reporting requirements for options issues coming into effect on August 29, 2002 as part of the Sarbanes-Oxley provisions. As of that date, options grants were required to be 
reported within two business days, in contrast to the long potential lags under previous regulations. This provided an opportunity to test the competing hypotheses as to whether the documented overall patterns of stock prices around options grants were the results of the "superior forecasting" ability of managers or "backdating." Lie's findings are definitively in support of the backdating hypothesis. In cases where the two-day reporting requirement is met, the patterns of "down before, up after" entirely disappears.

This paper focuses on the consequences of backdating. Firms are initiating investigations that are either internally initiated or undertaken by the SEC. Assuming compliance with Sarbanes-Oxley, the backdating being investigated took place before August 29, 2002. What are the consequences of the formal announcement of these investigations for the affected firms? They experience both the specific manifestation in accounting restatement and a general overall reputation impact. If backdating is found to have taken place, this will require restatement of financial statements for the affected interval and this paper now reviews the literature pertaining to accounting restatements.

\section{Accounting Restatements Literature}

An early major contribution to the restatement literature is that of Kinney and McDaniel (1989). They examined the characteristics of firms that correct previously reported quarterly earnings. In addition to typically negative reactions at the time of the restatement, Kinney and McDaniel also find negative abnormal returns between the issuance of erroneous quarterly reports and corrections. When investigating the attributes of firms that restate earnings, the authors found that firms making corrections are typically smaller, less profitable, more highly leveraged, slower growing, and received more qualified audit opinions than other firms in the same industry.

DeFond and Jiambalvo (1991) also find that earnings overstatements are negatively correlated with the growth in earnings. They also show that overstatements appear more often in those firms that have diffuse ownership, have lower growth in earnings and relatively fewer income-increasing GAAP alternatives available, and are less likely to have audit committees. After the early research cited above, subsequent studies examined auditor issues associated with firms making subsequent restatements. Kinney and McDaniel (1993) found significant increases in audit delay for firms correcting previously reported interim earnings.

Restatements are often associated with litigation against the firm's management and their auditors. The managers are sued because of misleading the investors or the intent to deceive. According to Section 10b of SEC Rule 10b-5 it is unlawful for managers to make an "untrue statement of a material fact or to omit to state a material fact necessary in order to make the statements made, in light of the circumstances in which they were made, not misleading". Francis et. al. (1994) note that "in a typical 10b-5 case plaintiffs allege they bought stock at inflated prices because managers misled the market by disseminating overly optimistic information or by failing to disclose material adverse information". While it is presently early in the investigative process, overstatements of earnings resulting from the issuance of in-the-money options would appear to provide a clear example of "overly optimistic information."

Owers, Lin and Rogers (2002) examined the stock price changes associated with the resolution of restatements. They identified 9 categories into which restatements can be classified and found statistically significant negative revaluations for the overall sample. However, there was substantial variation in valuation changes across the various categories of restatements. Investors react the most negatively to restatements resulting from accounting issues (i.e. errors/irregularities/method-changes). This is greatly magnified when there is a contemporaneous change in the firm's CEO. This scenario is found in many cases associated with the granting of backdated options.

In the context of the research into accounting restatements over the past two decades, it would seem that the extensive restatement activity resulting from the revelation of option backdating will generate a major extension of this line of investigation. 


\section{SAMPLE SELECTION AND DESCRIPTION}

The empirical sample and firm data were obtained from the following sources:

1. $\quad$ The Wall Street Journal;

2. Stock price data from http://finance.yahoo.com;

3. Company information from Lexis-Nexis; and

4. The "Press Releases" section of sample companies web-sites.

\section{Sample And Data}

Initially a text search was applied on Lexis-Nexis to identify the companies that are involved in the options backdating scandal. These companies are either under federal investigation or have launched their own internal investigations. The Key words used in these searches were: "OPTIONS" and "BACKDATING". Applying this process from December 2004 to December 2006 resulted in an initial sample of approximately 80 companies.

The date when the options scandal became public news for each company was identified in the following manner. A text search was performed on the online archives of the Wall Street Journal. The key words used in this search were: "OPTION" and 'The company name'. For each company, the date of the Wall Street Journal article that first mentioned its option scandal was noted. Also the "Press Releases" section of the company web-site was searched and date of the article which first mentioned the option scandal was noted. The earlier of the Wall Street Journal date and the date from the company web-site was taken as the "announcement" date.

During this sample identification process, confounding events were also identified. When major contemporaneous events occurred at the same time as involvement with options backdating problems the potential for a controlled analysis of the options implications was not present and the affected company eliminated from the empirical sample.

The historical stock price data was taken from the web-site: http://finance.yahoo.com. The stock price data in the interval $(-100,10)$ for each company was taken. Day 0 corresponds to the first date when the option backdating involvement of the company became public news as manifested in formal media reports. ${ }^{4}$

After the tests for data availability and an un-confounded announcement were completed, the empirical sample contained 57 firms. Although the sample selection process extended from December 2004 until December 2006, the majority (94.7\%) of the empirical sample announcements are in 2006. This reflects the fact that revelation of backdated options grants by specific firms is a relatively recent development.

\section{EMPIRICAL METHODS}

For purposes of examining the stock price reactions to the announcements, mean-deviation abnormal return methodology was employed. The statistical significance test of the cumulative abnormal returns was performed as follows: For each security $j$ the mean return is average return during the entire sample period. For each security the entire sample period consists of $(-100,10)$ days where the day 0 corresponds to the firm-specific event date (in this case the press release date). The benchmark mean return to be used for analyzing the event windows from day -20 until day +10 relative to the initial announcement was computed as:

$$
M R_{j t}=\sum_{t=-100}^{-21} R_{j t} / N
$$

\footnotetext{
${ }^{4}$ The potential for previous rumors is apparent and even receives mention in some of the formal press reports used to identify the "announcement date" for this study.
} 
where $\mathrm{N}$ is the number of days in the interval of the interval of estimation $(\mathrm{N}=80)$.

The abnormal return of each security $\mathrm{j}$ during the time-period $t$ is computed as:

$$
A R_{j t}=R_{j t}-M R_{j}
$$

The Cumulative Abnormal Return (CAR) for each security $j$ over a specified interval is the total of the abnormal returns during an interval $\left(-\mathrm{T}_{1}, \mathrm{~T}_{2}\right)$, where the firm-specific event has occurred at day $0 . \mathrm{T}_{1}$ is the number of days before day 0 and $T_{2}$ is the number of days after the event has occurred. The $\mathrm{CAR}_{\mathrm{j}}$ for each security $\mathrm{j}$ is computed as:

$$
\mathrm{C} A R_{\mathrm{j}}=\sum_{\mathrm{t}=-T 1}^{T 2} A R_{\mathrm{jt}},
$$

To form the interval test statistic, we first standardize the individual $\mathrm{CAR}_{j}$. The abnormal returns for different companies cannot be compared with each directly due to the different risk-return characteristics of the company. The cumulative abnormal return of each company has been standardized by dividing it by the standard deviation of the abnormal returns during the period $(-100,-21)$. Thus the standardized CAR (SCAR) gives the cumulative abnormal returns per unit standard deviation.

$\mathrm{S} C A R_{\mathrm{j}}=C A R_{\mathrm{j}} / s_{\mathrm{j}}$

where $s_{j}$ is the standard deviation of the abnormal returns of the security over the interval $(-100,-21)$.

$t=M S C A R / S T E r r$

is the test statistic employed to examine significance of abnormal returns over specified intervals. MSCAR is the mean SCAR across all the firms in the sample and STErr is the standard error. The STErr is the Standard Deviation of the SCAR across all the firms divided by the square-root of the number of firms in the sample.

\section{RESULTS}

The results are presented using two metrics. The first is the percentage Abnormal Returns (ARs) and the Cumulative Abnormal Returns (CARs) and the second the dollar values.

\section{Percentage Impact: Statistical Significance}

The statistical tests of significance of the cumulative abnormal returns (CARs) was undertaken in the customary manner. In the absence of a stock value reaction associated with the options backdating announcement, the abnormal returns for the companies over intervals around the initial announcement of backdating implications will be zero. Specifically, in the absence of any stock value consequences, CARs over the respective intervals ($20,10),(-10,0),(-1,+1),(-5,0),(0,5),(0,10)$ are hypothesized to be zero. Thus the average cumulative returns across all the companies within each of the intervals in the sample would in that case be zero.

A review of Table 1 indicates that there is notable negative stock value reaction associated with the first announcement of companies being implicated in options backdating. Table 1 provides daily average abnormal returns (ARs) and Table 2 reports mean CARs over the indicated announcement-relative intervals. Over the immediate announcement window $(-1,0)$ the average CAR is $-3.14 \%$. But this significant decline in value is 
markedly smaller than the wider intervals around the initial formal announcement. Over the 21 trading days (approximately a calendar month) ending with the formal announcement (i.e. -20,0) there is a notable mean CAR of $-11.54 \%$. Over $(-10,0)$ the average CAR is $-8.40 \%$ and over $(-5,0)$ it is $-5.49 \%$. These declines over the longer interval ending with the announcement are consistent with the notion that some information about the upcoming announcement is reaching the market. The potential involvement of the SEC and/or activities associated with internal investigations means that it seems reasonable to anticipate that well informed market participants might get a foreboding of the upcoming announcement. The patterns described above are clearly evident in Figure 1 that graphs the accumulation of the average CAR starting from day -20 .

Even after the announcement there is further average decline in values as evident from both Table 1 and Figure 1. Over the interval $(1,10)$ the average CAR is $-2.94 \%$. The ongoing negative abnormal returns in the days after the news became formally public could give rise to questions about the informational efficiency of the market. More likely, however, it is the result of ongoing resolution of uncertainty for investors as to the amount of reputational risk involved in the backdating scandal and the full consequences in terms of signals of deficient governance, caliber of the Board and management and internal controls.

Table 1

Daily mean Abnormal Returns (ARs) and Cumulative Mean Abnormal Returns (CARs) from day -20 relative to first press announcement that firm is embroiled in options backdating investigation.

\begin{tabular}{|c|c|c|}
\hline Day relative to day 0 announcement & Mean AR & Mean CAR From day -20 \\
\hline-20 & -0.00466 & -0.00466 \\
\hline-19 & -0.00286 & -0.00752 \\
\hline-18 & -0.00032 & -0.00784 \\
\hline-17 & -0.00894 & -0.01678 \\
\hline-16 & -0.00139 & -0.01817 \\
\hline-15 & -0.00384 & -0.02201 \\
\hline-14 & -0.00094 & -0.02295 \\
\hline-13 & -0.00427 & -0.02721 \\
\hline-12 & 0.00045 & -0.02717 \\
\hline-11 & -0.00418 & -0.03135 \\
\hline-10 & 0.00031 & -0.03103 \\
\hline-9 & -0.00577 & -0.03681 \\
\hline-8 & -0.01038 & -0.04719 \\
\hline-7 & -0.00497 & -0.05217 \\
\hline-6 & -0.00832 & -0.06048 \\
\hline-5 & -0.00681 & -0.06730 \\
\hline-4 & -0.00922 & -0.07651 \\
\hline-3 & -0.00798 & -0.08449 \\
\hline-2 & 0.00053 & -0.08396 \\
\hline-1 & -0.00906 & -0.09302 \\
\hline 0 & -0.02237 & -0.11539 \\
\hline 1 & -0.00459 & -0.11999 \\
\hline 2 & -0.00272 & -0.12271 \\
\hline 3 & -0.00339 & -0.12610 \\
\hline 4 & -0.00450 & -0.13060 \\
\hline 5 & -0.00724 & -0.13783 \\
\hline 6 & -0.00259 & -0.14043 \\
\hline 7 & 0.00337 & -0.13705 \\
\hline 8 & 0.00029 & -0.13676 \\
\hline 9 & -0.00478 & -0.14154 \\
\hline 10 & -0.00324 & -0.14477 \\
\hline
\end{tabular}


Figure 1

Graphical depiction of average CAR starting from 20 days before the formal press announcement (i.e. day -20$)$ to 10 days after the announcement (i.e. day 10) of a firm being embroiled in an investigation of the granting of backdated options.

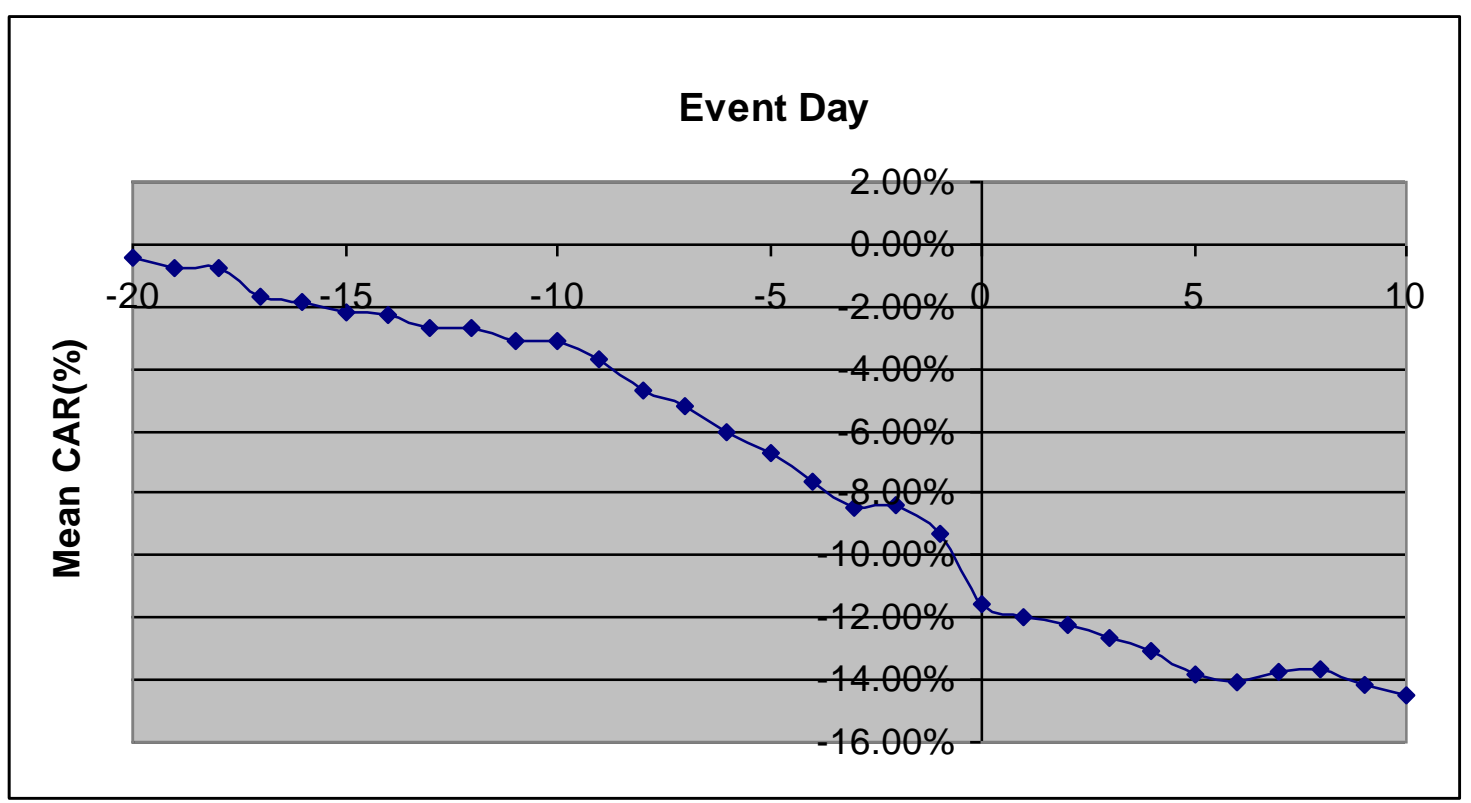

The average magnitudes of the drop in the returns around the announcement of the investigation can be observed by examining the mean CAR values for all 57 companies across specified intervals. These are reported in Table 2 .

Table 2

Mean Cumulative Abnormal Returns (CARs) for the 57 companies announcing investigations into the granting of backdated options during the interval from December 2004 through December 2006.

\begin{tabular}{|c|c|c|c|c|c|c|c|}
\hline Interval & $\mathbf{( - 2 0 , 0 )}$ & $\mathbf{( - 1 0 , 0 )}$ & $\mathbf{( - 5 , 0 )}$ & $\mathbf{( - 1 , 0 )}$ & $\mathbf{( - 1 , + 1 )}$ & $\mathbf{( 0 , 5 )}$ & $\mathbf{( 1 , 1 0 )}$ \\
\hline Mean CAR & -0.1154 & -0.0840 & -0.0549 & -0.0314 & -0.0360 & -0.0438 & -0.0294 \\
\hline T-Statistic & $-6.34^{*}$ & $-7.42^{*}$ & $-6.68^{*}$ & $-5.77^{*}$ & $-4.70^{*}$ & $-4.90^{*}$ & $-2.63^{* *}$ \\
\hline
\end{tabular}

* indicates significance at the $1 \%$ level; ** indicates significance at the $5 \%$ level

This examination of the mean standardized CARs in each of the specified intervals finds a very high level of statistical significance over each of the specified intervals relative to the formal announcement day 0. The CARs are statistically significant at the $1 \%$ level for each interval. This includes the post announcement interval of $(1,10)$ and $(0,5)$ intervals. It should be noted that it is also negative even in the intervals $(0,5)$ and $(0,10)$. As with the intervals ending with the formal announcement, there is a statistically significant drop in the returns days after the news becomes public.

\section{Monetary Impact: Economic Materiality}

Another measure of the consequences of formally becoming embroiled in an options backdating investigation is the change in the total value of the affected firms' equity. This is measured by calculating the change in each firm's market capitalization ("Market Cap.") and averaging this across all affected firms. This was undertaken over two intervals relative to the formal announcement. 
It was previously reported that the average CAR over $(-20,0)$ was $-11.54 \%$. What does this represent in terms of monetary values? To undertake the calculation of the impact on the market capitalization of each sample firm, the CAR over the relevant interval was applied to the market capitalization at a point in time presumably before any impact of the upcoming announcement was affecting the stock value. The benchmark for this calculation was taken as the market capitalization at day -21 . The change in market capitalization for each sample firm was then averaged to find the average impact for affected firms.

On average, the decline in a firm's market capitalization was a notable $\$ 542,434,194$. At more than half a billion dollars, this is a large number by any scale. The change was negative for $77.2 \%$ of the sample firms. Given the filtering for confounded events described earlier, those firms that did not have a negative reaction associated with the announcement might well have been subject to prior rumors at which time the stock value may have responded to the anticipated effect. As noted previously, this study restricted the "announcement date" identification to formal press releases in the established financial press or on the company website.

Over the narrower event related window $(-5,0)$ the average change in market capitalization is $\$ 236,457,035$. This is just less than a quarter billion dollars and $81.7 \%$ of the sample firms experienced decreases in market capitalization.

It is clear that the average decline in equity value for firms subject to investigation of granting back dated options is large and in most cases this decline greatly exceeds the resulting gains to recipients. The concept of direct costs and indirect consequences are evident and demonstrate the reputational risk associated with practices such as granting backdated options.

The direct costs might be considered to be the understated compensation and associated fines and penalties. The indirect costs are the dimensions associated with investors' downgrading of affected firms' management ethical coordinates and governance procedures. This is reflected in the reported challenges the SEC is facing in deciding how much companies and their shareholders were negatively affected by the process of backdating. The Chairman of the SEC was reported as saying that "We are relying heavily on the resources of the Office of Economic Analysis and our chief economist. Each case rather obviously will turn on some facts, so we'll take them one at a time as they come." Given that the average negative monetary impact in terms of decline in market capitalization is in most cases many times the amount of the benefit to the recipients, the challenges are understandable.

\section{CONCLUSIONS}

This paper examines the impact of firms formally becoming embroiled in option backdating investigations. The investigations can be instigated externally (e.g. by the SEC) or internally in response to concerns of such practices. Such practices clearly carry a high level of associated reputational risk. The presence of backdating potentially signals substantial concerns regarding governance and legal exposure.

For confidence in markets as a whole, the revelation of seemingly widespread option backdating is an additional negative. There has been a notable increase in accounting restatements in recent years and the need to restate financials has received another boost as the extent of the granting of backdated options is becoming apparent. The fortuitous timing of stock options grants has been documented for approximately a decade but until recently the competing hypotheses of "good forecasting ability by top executives" versus "mischief by backdating" had not been tested. The changes in reporting options grants contained in Sarbanes-Oxley provided the opportunity to test these hypotheses definitively and the backdating hypothesis is overwhelmingly supported.

The market reaction to formal announcements of options backdating investigations is quite dramatic. Over the customary narrow event window $(-1,0)$ firms experience average abnormal return losses of $3.14 \%$. The losses build before the formal announcement so that longer intervals both before and after the formal announcement see

\footnotetext{
${ }^{5}$ The Wall Street Journal, March 08, 2007, P. C1
} 
larger abnormal losses in equity values. Over $(-20,0)$ the average CAR is $-11.54 \%$ and over $(1,10)$ another $-2.94 \%$. These magnitudes are all statistically significant as discussed.

In addition to the statistical metrics, the average loss in market capitalization over he $(-20,0)$ interval was more than $\$ 542$ million. Over the shorter $(-5,0)$ interval the average decline in market capitalization was more than $\$ 236$ million. These magnitudes are a multiple of the direct costs and indicate the magnitude of reputational risk associated with such practices. On average stockholders experience major losses and overall declines in value are notable. The direct losses in terms of unreported compensation paid to the recipients and associated fines and penalties are seemingly a small fraction of the overall decline in firm value. Presumably the direct losses are just a part of the overall losses with deterioration in perceptions of governance and managerial ethics contributing additionally to the overall economic losses for the shareholders of affected firms. An analysis of the factors leading to the decline in overall firm equity value at the time of formal announcements of options backdating investigations would appear to be an area for fruitful investigation for additional calibration relating to reputational risk.

\section{REFERENCES}

1. Aboody, D., and R. Kasznik, 2000, CEO stock option awards and the timing of corporate voluntary disclosures, Journal of Accounting and Economics 29, 73-100.

2. American Institute of Certified Public Accountants, 1984, Statement on Auditing Standards No. 53, The Auditor's Responsibility to Detect and Report Errors and Irregularities.

3. Benston, G.J., 1975, Accountant's integrity and financial reporting, Financial Executive, Aug., 10-14.

4. Brumfield, C. A., R. K. Elliott, and P. D. Jacobson, 1983, Business risk and the audit process, Journal of Accountancy 155 (April), 60-68.

5. Carpenter, J.N., and B. Remmers, 2001, Executive stock option exercise and inside information, Journal of Business 74, 513-534.

6. Chauvin, K. W., and C. Shenoy, 2001, Stock price decreases prior to executive stock option grants, Journal of Corporate Finance 7, 53-76.

7. DeFond, Mark L. and James Jiambalvo, 1991, Incidence and circumstances of accounting errors, The Accounting Review 66, No. 3, 643-655.

8. Francis, Jennifer, Donna Philbrick, and Katherine Schipper, 1994, Shareholder litigation and corporate disclosures, Journal of Accounting Research 32, No. 2, 137-164.

9. Heron, R.A., and E. Lie, 2007, Does backdating explain the stock price pattern around executive stock option grants, Journal of Financial Economics, forthcoming.

10. Kellogg, R. L., 1984, Accounting activities, security prices, and class action suits, Journal of Accounting and Economics 3, 185-204.

11. Kinney, W. R. and L. S. McDaniel, 1989, Characteristics of firms correcting previously reported quarterly earnings, Journal of Accounting and Economics 11, 71-93.

12. _ _ and _ 1993, Audit delay for firms correcting quarterly earnings, Auditing: A Journal of Practice \& Theory 12, No. 2, 135-142.

13. Krishnan, J., and J. Krishnan, 1997, Litigation risk and auditor resignations, The Accounting Review 72, No.4, 539-560.

14. Lie, E., 2005 On the timing of CEO stock option awards, Management Science 51, 802-812.

15. Lys, T. and R. L. Watts, 1994, Lawsuits against auditors, Journal of Accounting Research 32 (Supplement), 65-93.

16. MacDonald, E., and E. Brown, 2005. Thumbs on the scale, Forbes.com (Nov. 28 ${ }^{\text {th }}$ )

17. Monks, R. G. A. and N. Minnow, Corporate Governance, 2nd Edition, Blackwell Publishing, 2000

18. Owers, J.E., C.M. Lin and R. C. Rogers, 2002, The Informational Content and Valuation Ramifications of Earnings Restatements, International Business and Economics Research Journal, 1, No. 5, 71-84.

19. Palmrose, Z., 1988, An analysis of auditor litigation and audit service quality, The Accounting Review 63 (January), 55-73.

20. Pratt, J. and J. D. Stice, 1994, The effects of client characteristics on auditor litigation risk judgments, required audit evidence, and recommended audit fees, The Accounting Review 69, No. 4, 639-656.

21. Securities and Exchange Commission, 1979, Securities Act of 1933, Rel. No. 6084, Sec Docket 1048. 
22. __ 1988, Financial Reporting Release No. 31, Commerce Clearing House, Chicago.

23. Siliciano, J. A., 1988, Negligent accounting and the limits of instrumental tort reform, Michigan Law Review 86 (August), 1929-1980.

24. Stice, James D., 1991, Using financial and market information to identify pre-engagement factors associated with lawsuits against auditors, The Accounting Review 66 (July), 516-533.

25. Sullivan, J. D., 1992, Litigation risk broadly considered, In Auditing Symposium XI: Proceedings of the 1992 Deloitte \& Touche/University of Kansas Symposium on Auditing Problems, 49-59. University of Kansas, KS: School of Business.

26. Turner, L., and T. Weirich, 2007, A Closer Look at Financial Statement Restatements, CPA Journal, 76, No. 12, 13-23.

27. Willingham, John J. and William F. Wright, 1985, Financial statement errors and internal control judgments, Auditing: A Journal of Practice \& Theory 5, No. 1, 57-70.

28. Yermack, D., 1997, Good timing: CEO stock option awards and company news announcements, Journal of Finance 52, 449-476.

\section{NOTES}

